\title{
MODEL KEPEMIMPINAN KYAI DALAM MEMBENTUK SANTRI MANDIRI di ERA 4.0
}

\author{
Imam Safi'i \\ Universitas Islam Malang, Indonesia \\ Imam.safii@unisma.ac.id
}

Received: 11-04-2020

Revised: 05-06-2020

Accepted: 28-06-2020

\section{Model of Kyai Leadership in Forming Independent Santri In The Era 4.0}

\section{Abstract}

The research aimed to ; 1) describe and analyse how the leadership type of Kyai Mohammad Ali Shobirin in forming independent santri; 2). what kind of habits were done in the Islamic dorm of al Qoyyim , to form independent santri; 3). model of Kyai Ali shobirin leadership in forming independent santri in the islamic dorm Al Qoyyim Kasembon Malang. The applied research method to answer the aim above was grounded theory, because the research was field research. While the references consisted of primary, secondary and tertiary data. Collecting data by observation, interviews and documentation. Data analyze used qualitattive data analyze. The research showed that kyai Ali Shobirin belonged to the one of three type of leadership. Firstly, visionary leadership. Secondly, transformative leadership. Thirdly, charismatic leadership. The habit of Santri to form independent santri in the era 4.0 was discipline in every aspect, santri's habituality to be entrepeneur and The model of leadership of kyai Ali Shobirin was individual-kolektif, it happened because collaboration in developing Islamic dorm. While, the policy was taken by the head dominantly.

Keywords : Leadership model, Kyai, Independent Santri, Industry 4.0

\begin{abstract}
Abstrak
Peneliti ini bertujuan untuk: Mendeskripsikan dan menganalisa bagaimana tipe kepemimpinan Kyai Mohammad Ali Shobirin didalam mencetak santri yang mandiri. Pembiasaan yang seperti apa dilakukan pondok pesantren al Qoyyim untuk mencetak santri mandiri. Model Kepemimpinan Kyai Ali shobirin dalam mencetak Santri Mandiri di pondok pesantren Al Qoyyim Kasembon Malang. Metode penelitian yang dipakai untuk menjawab tujuan diatas adalah grounded theory, karena penelitian bersifat lapangan, yang mana penelitian ini referensinya terdiri dari data primer, sekunder dan tersier. Teknik pengumpulan data melalui studi observasi, interview dan dokumentasi. Analisis data menggunakan analisis data kualitatif. Hasil penelitian ini bahwa kyai Ali Shobirin adalah pemimpin yang masuk dalam tiga tipe yaitu tipe pertama, Pemimpin yang visioner kedua, pemimpin transformasional ketiga, Pemimpin yang kharismatik. Pembiasaan santri untuk mencetak santri yang mandiri di Era Revolusi Industri 4.0 yaitu pembiasaan santri agar selalu disiplin dalam semua hal, pembiasaan santri berwirausaha. dan kyai Ali Shobirin termasuk model kepemimpinan individual-kolektif disebabkan dengan kolaborasi dalam mengembangkan pondok pesantren akan tetapi kebijakan masih sangat dominan dimiliki oleh pengasuh.

Kata Kunci: Model kepemimpinan, Kyai, Santri Mandiri, Industri 4.0
\end{abstract}




\section{PENDAHULUAN}

Pesantren adalah sebuah tempat untuk belajar keilmuan agama secara mendalam sesuia dengan kajian-kajian al quran ,hadist dan kitab-kitab kuning ${ }^{1}$. Kehadiran pesantren sebagai sebuah lembaga pendidikan islam ditengah masyarakat Indonesia sebuah hasil dari budaya yang tercermin dari cara hidup santri dan masyarakat Indonesia ${ }^{2}$. Pesantren mempunyai kekhasan khusus untuk mengembangkan lembaga dan mencetak santri yang mandiri di bidang agama,sosial dan ekonomi ${ }^{3}$. Hal ini seperti yang terjadi di pondok pesantren Al Qoyyim Kecamatan Kasembon, Kabupaten Malang, oleh karenanya ini menjadi sesuatu yang sangat penting untuk di teliti di masa sekarang untuk menjawab kebutuhan Era 4.0.

Kepemimpinan kyai dan visi misi pondok pesantren Al Qoyyim Kecamatan Kasembon, Kabupaten Malang menggambarkan bagaimana santri agar bisa menjawab kebutuhan di masa sekarang dengan adanya dinamika yang baik ,menciptakan sebuah lingkungan yang menjadikan santri yang mandiri. Kyai ali shobirin selalu memberikan motivasi kepada para santri agar selalu mempunyai usaha, agar nanti ketika berdakwah di masyarakat tidak kebingungan secara materi dan harus terus mengembangkan diri. $^{4}$

Pondok pesantren menjadi tempat yang bisa menjawab kebutuhan untuk membentuk karakter santri dikarenakan didalam pondok pesantren digembleng oleh kyai selama 24 jam penuh,ini yang menjadikan lebih cepat santri mempunyai karakter mandiri. Para santri selalu termotivasi dengan apa yang didawuhkan pengasuhnya,karena kyai Ali shobirin tidak hanya berbicara akan tetapi memberikan teladan dengan melakukan usaha-usaha seperti tambak ikan, kolam lele, pembuatan es crem dan rias untuk santri putri. ${ }^{5}$

${ }^{1}$ Van Bruinessen Martin, Kutab Kuning Pesantren dan Tarekat, 1 ed. (Yogyakarta: Gading Publising, 2012); Ziemek Manfred, Pesantren Dalam Perubahan Sosial (Jakarta: P3M, 1983); Zamakhsyari Dhofier, Tradisi pesantren: studi pandangan hidup kyai dan visinya mengenai masa depan Indonesia, Cet. 8 rev (Jakarta: LP3ES, 2011).

2 Naufal Ahmad Rijalul Alam, "Strengthening Leadership Culture (The Role of Kyai in Indonesian Pesantren)," At-Ta'dib 13, no. 1 (2018): undefined-undefined, https://doi.org/10.21111/at-tadib.v13i1.1986; Hanun Asrohah, "The Dynamics of Pesantren: Responses Toward Modernity and Mechanism in Organizing Transformation," Journal of Indonesian Islam 5, no. 1 (1 Juni 2011): 66-90, https://doi.org/10.15642/JIIS.2011.5.1.66-90; Effendi Chairi, "Pengembangan Metode Bandongan Dalam Kajian Kitab Kuning Di Pesantren Attarbiyah Guluk-Guluk Dalam Perspektif Muhammad Abid al-Jabiri," Nidhomul Haq: Jurnal Manajemen Pendidikan Islam 4, no. 1 (15 Maret 2019): 70-89, https://doi.org/10.31538/ndh.v4i1.233.

3 Mochammad Zaka Ardiansyah, "Pesantren Hybrid Worldview: Moderatisasi Paradigma Penalaran Keislaman dan Pemenangan Kontestasi Wacana Daring," Jurnal Pendidikan Agama Islam (Journal of Islamic Education Studies) 7, no. 1 (5 Juli 2019): 1-18, https://doi.org/10.15642/jpai.2019.7.1.1-18; Chusnul Chotimah, "Pendidikan Kewirausahaan Di Pondok Pesantren Sidogiri Pasuruan," Inferensi: Jurnal Penelitian Sosial Keagamaan 8, no. 1 (2014): 114-36, https://doi.org/10.18326/infsl3.v8i1.114-136.

${ }^{4}$ Hasil Observasi, 12 Maret 2019

${ }^{5}$ Hasil Observasi, 12 Maret 2019 
Bahwa pondok peantren adalah suatu lembaga dimana sistem pendidikan adalah kyai dan santri hidup bersama dalam satu tempat yang disebut pesantren.metode yang dikembangkan didialam pondok pesantren sangat bervariatif melalui mengajar (dirasah wa ta'lim),pembiasaan berperilaku luhur (ta'dib) aktivitas spiritual (riyadhah) serta teladan yang baik (uswah hasanah) dari kyai.

Pondok pesantren al Qoyyim juga memeberikan pelatihan-pelatihan untuk mempersiapkan santrinya nanti agar menjadi santri yang betul-betul mandiri secara ekonomi dan mampu memeberikan kemanfaatan kepada masyarakat. Ini terbukti bahwa dipondik pesantren al Qoyyim tidak hanya belajar ngaji agama tapi juga diajarai soft skill. Pondok sini santri juga sudah biasa dengan media onlain, karena santri wajib mengikuti pelatihan computer dan pemasaran usaha secara dariing. Maka dari itu berangkat dari konteks penelitian yang dijabarkan diatas menjadi dasar peneliti untuk melakukan penelitian tentang model kepemimpinan kyai dalam membentuk santri mandiri di Era 4.0 di pondok pesantren $\mathrm{Al}$ Qoyyim Kecamatan Kasembon, Kabupaten Malang”.

\section{METODE PENELITIAN}

Penelitian di pondok pesantren Al Qoyyim Kasembon Malang menggunakan pendekatan Deskriptif-Kualitatif, Bogdan dan Taylor yang dikuti Moelong mendefinisikan “Metodologi Kualitatif” sebagai prosedur penelitian yang menghasilkan data deskriptif berupa kata-kata tertulis atau lisan dari orang-orang dan perilaku yang dapat diamati. Menurut mereka, pendekatan ini, diarahkan pada latar dan individu tersebut secara holistik (utuh). Jadi, dalam hal ini tidak boleh membedakan apa yang terjadi secara nyata dalam pesarean gunung kawi ke dalam variabel atau hipotetis, tetapi perlu memandangnya sebagai bagian dari suatu keutuhan. ${ }^{6}$

Deskriptif Kualitatif adalah penelitian yang data-datanya berupa kata-kata (bukan angka-angka, yang berasal dari wawancara, catatan laporan, dokumen dll) atau penelitian yang di dalamnya mengutamakan untuk pendiskripsian secara analisis sesuatu peristiwa atau proses sebagaimana adanya dalam lingkungan yang alami untuk memperoleh makna yang mendalam dari hakekat proses tersebut?

Sedangkan jenis penelitiannya adalah fenomenologi. Dimana upaya menggali makna berdasarkan suatu peristiwa yang ikut dialami. Fenomenologi diartikan sebagai pengalaman subjektif atau pengalaman fenomenologikal atau suatu kajian tentang prespektif perilaku

\footnotetext{
${ }^{6}$ Moloeng Lexy J, Metodologi penelitian Kualitatif, 29 ed. (Bandung: Rosdakarya, 2011), 24.

${ }^{7}$ Nana Sudjana, Penelitian dan penilaian pendidikan (Sinar Baru, Bandung, 1989).
} 
sesorang. ${ }^{8}$ Fenomenologi kadang digunakan sebagai prespektif filosofis dan kadang pula digunakan sebagai pendekatan metodologi kualitatif.' Menurut Creswell, fenomenologi merupakan strategi penelitian yang mengharuskan peneliti bisa mengidentifikasi hakikat pengalaman manusia tentang suatu fenomena. Memahami pengalaman hidup manusia dengan menjadikannya fenomenologi sebagai metode penelitian yang mengharuskan peneliti mengkaji sejumlah subjek yang terlibat langsung secara aktif didalamnya. ${ }^{10}$

\section{PEMBAHASAN}

\section{Tipe Kepemimpinan Kyai Mohammad Ali Shobirin}

Menurut Suharto kyai adalah sosok figure yang sentral disetiap pesantren,dimana seorang kyai menjadi penyampai ilmu dan juga pendiri,perintis, pemilik pesantren. Seperti kyai ali shobirin juga menjadi sentral figur di pondok pesantren Al Qoyyim,serta beliau menjadi pendiri sekaligus pengasuh pondok pesantren Al Qoyyim. Teladan kyai melalui perkataan dan tindakan ini membuat satu hal yang selalu di ingat oleh para santrinya dan terus diikuti walaupun sudah menjadi alumni hidup dimasyarakat. Seperti apa yang disampaikan salah satu alumni al qoyyim,bahwa romo kyai memberikan teladan dalam hal ibadah dan sekaligus amaliah sehari-hari misalnya tentang ibadah sholat jamaah,kesabarannya dan kemandirian dalam ekonomi. ${ }^{11}$ inilah yang memberikan berbeda seorang kyai dengan yang lainnya karena tidak hanya pandai menyampaikan ilmu tapi juga langsung memberikan contoh apa yang sudah dijelaskan ke para santrinya.

Perkataan dan perbuatan kyai menjadi menyatu mendarah daging dalam kehidupan santri di pondok pesantren al qoyyim,mereka para santri mengikuti apa yang dikatan para santri dan meneladani apa yang sudah dilakukan Kyai,tidak hanya santri tapi masyarakat juga merasakan kehadiran seorang kyai menjadi figure yang sangat baik,sederhana dan merakyat. Dari beberapa pendapat dari santri dan masyarakat sekitar pondok bahwa tipe kepemimpinan kyai ali shobirin dapat diklasifikasikan sebagai berikut:

\section{Tipe Pemimpin Visioner}

Seorang pemimpin atau seorang kyai tidak hanya mempunyai manjerial yang baik akan tetapi juga memiliki pandangan jauh kedepan dalam rangka mengembangkan pondok pesantren dan mencetak santri yang sanggup menjawab tantangan masa depan. Pemimpin

${ }^{8}$ Clark E. Moustakas, Phenomenological Research Methods, 6. print. (Thousand Oaks, Calif.: Sage Publ, 1999).

9 Arikunto Suharsimi, Prosedur Penelitian, Suatu Pendekatan Teori dan Praktek, 14 ed. (Jakarta: Rineka Cipta, 2010).

${ }^{10}$ John W. Creswell, Qualitative inquiry \& research design: choosing among five approaches, 2nd ed (Thousand Oaks: Sage Publications, 2007).

${ }^{11}$ Hasil wawancara dengan Syifa salah satu alumni PP Al Qoyyim Malang, 14 September 2019 
harus mempunyai sebuah visi atau gambaran yang jelas untuk masa depan,mampu memahami,menganalisis perkembangan zaman dan terus melalukan inovasi-inovasi dalam mewujudkan visinya. Secara umum visi diartikan suatu gambaran mengenai masa depan yang diinginkan dan direncanakan bersama ${ }^{12}$.

Kyai Ali Shobirin mempunyai tekat yang kuat untuk mewujudkan pondok pesantren enterprenership dan mempunyai 100 cabang pondok pesantren. Santri harus mempunyai cita-cita untuk memberikan manfaat kepada banyak orang, dan santri agar mandiri secara ekonomi serta keilmuan keagamaan yang kuat. Saya juga mempunyai keinginan kedepan mempunyai 100 cabang pondok al Qoyyim, sekarang masih terwujud 6 pondok. Yaitu pertama di pondok pesantren sentral Al qoyyim kasembon,kedua pondok al Qayyim yang dikelola putranya di kasembon, ketiga ada cabang pondok khusus jompo dirumah sakit kasembon, keempat pondok cabang di lamongan, kelima pondok cabang yang ada di Kediri dan keenam cabang pondok di Tuban ${ }^{13}$.

Integritas dan semangat yang dimiliki kyai untuk terus bermanfaat terhadap banyak orang menjadikan satu kekuatan dalam mengembangkan lembaga pondok pesantrennya. Pemimpin memang harus memiliki sikap fokus untuk merekasa dalam meraih cita-cita yang diharapkan dan pada waktunya akan menunjukkan pemimpin yang berkualitas. Menurut John Adair bahwa ciri-ciri pemimpin yang berkualitas, yaitu: 1) memiliki intergritas pribadi, 2) memiliki antusiasme terhadap perkembangan lembaga yang dipimpinya, 3) mengembangkan kehangatan, budaya, dan iklim organisasi, 4) memiliki ketenangan dalam manajemen organisasi, dan 5) tegas dan adil dalam mengambil tindakan/kebijakan kelembagaan ${ }^{14}$.

Sikap antusiasme yang tinggi untuk menjadikan para santri mampu menjawab masa depan ini betul-betul dirasakan oleh para santri,seperti yang disampaikan oleh salah satu alumni pondok pesantren Al Qoyyim: Belajar dipondok pesantren al Qoyyim menjadikan saya mempunyai semangat untuk menatap masa depan dan ini terbukti ketika dimasyarakat bisa mandiri dengan membuka tambak ikan,ada juga yang membuka salon yang santri putri. $^{15}$

12 Burt Nanus dan Frederik Ruma, Kepemimpinan Visioner (Jakarta: Prenhallindo, 2001), 77.

13 (Hasil Wawancara dengan Kyai Ali Shobirin,14.09.2019).

14 Aan Komariah dan Dedy Achmad Kurniady, "Authentic Leadership: Strategy of the Implementation of Madrasah Management of Change," Jurnal Pendidikan Islam 6, no. 2 (27 Desember 2017): 293-310, https://doi.org/10.14421/jpi.2017.62.293-310; Komariah Aan dan Triatna Cepi, "Visionary Leadership Menuju Sekolah Efektif," Jakarta: Bumi Aksara, 2005, 82.

${ }^{15}$ Hasil wawancara dengan sifa' alumni Pondok Pesantren Al Qoyyim 04.03.2020 
Pemimpin atau pengasuh pondok pesantren yang visioner akan menunjukkan apa yang dikerjakan itu dilakukan secara bersama-sama oleh para anggotanya dengan cara memberikan arahan dan makna pada apa yang dilakukan sesuai dengan visi yang diharapkan. ${ }^{16}$ Pemimpin visioner memiliki ciri-ciri yang menggambarkan segala sikap dan perilakunya yang menunjukkan kepemimpinannya yang berorientasi kepada pencapaian visi, jauh memandang ke depan dan terbiasa menghadapi segala tantangan dan resiko. Diantara ciri-ciri utama kepemimpinan visioner adalah ${ }^{17}$ :

Pertama, berwawasan ke masa depan, bertindak sebagai motivator, berorientasi pada the best performance untuk pemberdayaan, kesanggupan untuk memberikan arahan konkrit yang sistematis. Kedua, berani bertindak dalam meraih tujuan, penuh percaya diri, tidak peragu dan selalu siap menghadapi resiko. Pada saat yang bersamaan, pemimpin visioner juga menunjukkan perhitungan yang cermat, teliti dan akurat. Memandang sumber daya, terutama sumberdaya manusia sebagai asset yang sangat berharga dan memberikan perhatian dan perlindungan yang baik terhadap mereka. Ketiga, mampu menggalang orang lain untuk kerja keras dan kerjasama dalam mencapai tujuan, menjadi model (teladan) yang secara konsisten menunjukkan nilai-nilai kepemimpinannya, memberikan umpan balik positif, selalu menghargai kerja keras dan prestasi yang ditunjukkan oleh siapun yang telah memberi kontribusi ${ }^{18}$. Keempat, mampu merumuskan visi yang jelas, inspirasional dan menggugah, mengelola 'mimpi' menjadi kenyataan, mengajak orang lain untuk berubah, bergerak ke 'new place'. Mampu memberi inspirasi, memotivasi orang lain untuk bekerja lebih kreatif dan bekerja lebih keras untuk mendapatkan situsi dan kondisi yang lebih baik ${ }^{19}$.

Kelima, mampu mengubah visi ke dalam aksi, menjelaskan dengan baik maksud visi kepada orang lain, dan secara pribadi sangat commited terhadap visi tersebut. Keenam, berpegang erat kepada nilai-nilai spiritual yang diyakininya. Memiliki integritas kepribadian yang kuat, memancarkan energy, vitalitas dan kemauan yang membara untuk selalu berdiri

${ }^{16}$ Yuni Siswanti, Meraih Kepemimpinan Manajerial yang 'smart’ (Wimaya Press, Yogyakarta, 2008), 11.

17 C.F. Achua dan R.N. Lussier, Effective Leadership (Canada: South-Western, 2009), https://books.google.co.id/books?id=W-_wPgAACAAJ; Ari Kartiko dkk., "The Influence of Leadership, Compensation on Nurses' Performance in the Mother and Child Hospital 'Fatimah' Lamongan' (Proceedings of the 2nd International Conference on Economics, Business, and Government Challenges, EBGC 2019, 3 October, UPN “ Veteran” East Java, Surabaya, Indonesia, Indonesia: EAI, 2020), http://dx.doi.org/10.4108/eai.3-10-2019.2291913.

18 Muhammad Latif Fauzi, "Traditional Islam in Javanese Society: The Roles of Kyai and Pesantren in Preserving Islamic Tradition and Negotiating Modernity," Journal of Indonesian Islam 6, no. 1 (1 Juni 2012): 125-44, https://doi.org/10.15642/JIIS.2012.6.1.125-144.

${ }_{19}$ Benny Prasetya, "Kompetensi Kepribadian Guru Pai Dalam Memotivasi Belajar Siswa," Edukasi: Jurnal Pendidikan Islam 1, no. 2 (2013): $225-238, \quad$ http://ejournal.staimtulungagung.ac.id/index.php/EDUKASI/article/view/171. 
pada posisi yang segaris dengan nilai-nilai spiritual. Menjadi orang yang terdepan dan pertama dalam menerapkan nilai-nilai luhur, sebagaimana yang diungkapkan oleh Mahatma Gandhi: "I must first be the change I want to see in my world. Ketujuh, membangun hubungan (relationship) secara efektif, memberi penghargaan dan respek. Sangat peduli kepada orang lain (bawahan), memandang orang lain sebagai asset berharga yang harus di perhatikan, memperlakukan mereka dengan baik dan 'hangat' layaknya keluarga. Sangat responsif terhadap segala kebutuhan orang lain dan membantu mereka berkembang, mandiri dan membimbing menemukan jalan masa depan mereka. Kedelapan, inovatif dan proaktif dalam menemukan 'dunia baru'. Membantu mengubah dari cara berfikir yang konvensional (old mental maps) ke paradigm baru yang dinamis. Melakukan terobosan-terobosan berfikir yang kreatif dan produktif. Lebih bersikap atisipatif dalam mengayunkan langkah perubahan ${ }^{20}$.

Pengasuh pondok pesantren Al Qoyyim ini mempunyai mimpi yang besar dan mempunyai keberanian dalam mengambil sikap dalam pengembangan lembaganya serta mempunyai spiritualitas yang tinggi. Ini terbukti dengan selalu menguatkan kepada para santrinya untuk terus yaqin kepada Allah Swt bahwa ketika kita berniat untuk melakukan kebaikan untuk banyak orang maka Allah yang akan mencukupi semua apa yang kita inginkan ,dengan begitu jangan pernah tidak yakin dengan apa yang di ihtiarkan untuk meraih masa depan lebih gemilang.

Seorang pemimpin memang seharusnya mempunyai visi yang jelas dalam mengembangkan lembaga dan melakukan langkah-langkah terprogram untuk meraih visi yang diharapkan. Juga harus selalu melakukan programnya terukur dan dikerjakan bersamasama $^{21}$. Kyai berwawasan Visioner merupakan kepemimpinan yang memberikan partisipasi ustadz, santri dan orang tua secara bersama- sama untuk memajukan sekolah ${ }^{22}$. Karateristik Kyai berwawasan visoner-transformatif akan membangun organisasi yang berwawasan masa depan dengan landasan dasar pada artikulasi visi dan misi, dalam budaya organisasi, budaya kerja dan iklim pondok pesantren ${ }^{23}$. Ia mampu melakukan perubahan-perubahan

${ }^{20}$ Mohammad Masrur, "Figur Kyai Dan Pendidikan Karakter Di Pondok Pesantren," Tarbawiyah Jurnal Ilmiah Pendidikan 14, no. 02 (2018): 272-82, https://www.mendeley.com/catalogue/figur-kyai-dan-pendidikankarakter-di-pondok-pesantren/.

${ }^{21}$ J. Stewart Black dan Allen J. Morrison, "The Character of Global Leaders," dalam Advances in Global Leadership, vol. 8, 0 vol., Advances in Global Leadership 8 (Emerald Group Publishing Limited, 2014), 183-204, https://doi.org/10.1108/S1535-120320140000008016.

${ }^{22}$ Kusmana Kusmana, "Pesantren and Local Female Leadership in Modern Indonesia," TARBIYA: Journal of Education in Muslim Society 6, no. 1 (29 Desember 2019): 23-35, https://doi.org/10.15408/tjems.v6i1.8919.

${ }^{23}$ Bashori Bashori, "Modernisasi Lembaga Pendidikan Pesantren Perspektif Azyumardi Azra," Nadwa 11, no. 2 (17 November 2017): 269, https://doi.org/10.21580/nw.2017.11.2.1881. 
edukatif dalam rangkah meningkatkan kualitas pendidikan dengan mempertahankan prisipprinsip dari pada pendidikan di pondok pesantren. Visi pondok pesantren pada intinya adalah statemen paling fundamental (fundamental statement) mengenai nilai, aspirasi dan tujuan institusi persekolahan. Oleh karenaitu, visi merupakan kunci keberhasilan sebuah lembaga yang dikelola secara profesional. Dengan visi itu seluruh komunitas lembaga (kepala sekolah, guru, staf, tata usaha, laboran, teknisi sumber belajar dan lain sebagainya) ${ }^{24}$

\section{Tipe Pemimpin Transformational}

Kepemimpinan kyai Ali Shobirin menggambarkan pemimpin yang transformational dengan cara melakukan pengkaderan untuk putranya dan santrinya yang setelah itu diberi tanggung jawab untuk memimpin pondok pesantren cabang. Akan tetapi tetap semuanya dalam naungan pondok pesantren pusat yang langsung di pimpin oleh Kyai Alin shobirin. Hal ini sesuai dengan apa yang dilihat oleh peneliti:

Dibeberapan pondok pesantren cabang itu diasuh oleh putranya dan ada juga yang di asuh oleh santrinya. di Pondok Pesantren Al Qoyyim 2 yang ada di kasembon itu di asuh oleh Putranya dan yang dilamongan itu diasuh oleh santrinya. ${ }^{25}$ Leithwood menegaskan bahwa kepemimpinan transformasional menggiring SDM yang dipimpin kearah tumbuhnya sensitivitas pembinaan dan pengembangan organisasi, pengembangan visi secara bersama, pendistribusian kewenangan kepemimpinan dan membangun kultur organisasi“ “. ${ }^{26}$

Pembinaan yang dilakukan oleh kyai ali shobirin tidak hanya itu akan tetapi bagaimana santri,wali santri dan masyarakat betul-betul yakin dengan apa yang dilakukannya. Hal ini menjadikan para santri,wali santri,masyarakat betul-betul mematuhi apa yang didawuhkan oleh kyai. Pendekatan Romo kyai untuk menjadikan para santri,wali santri dan masyarakat agar betul-betul yaqin dan mengikuti apa yang di dawuhkan yaitu dengan cara menyampaikan ilmu dan memberikan contoh langsung,dan juga melakukan rutinan sholawatan, dzikiran yang langsung dipimpin oleh kyai. ${ }^{27}$

Kalau dikaitkan dengan teori kepemimpinan transformasional, maka hal ini sesuai dengan teori yang diformulasikan oleh Bass ${ }^{28}$ bahwa tingkat sejauh mana seorang pemimpin disebut transformasional terutama diukur dalam hubungannya dengan efek pemimpin

27.

${ }^{24}$ Sudarman Darwin, Visi Baru Manajemen Sekolab; Dari Unit Birokrasi ke Lembaga Akademik (Jakarta, 2006),

${ }^{25}$ Hasil Observasi 4 Maret 2020

26 S. Danim, Menjadi komunitas pembelajar: kepemimpinan transformasional dalam komunitas organisasi pembelajaran (Bumi Aksara, 2003), https://books.google.co.id/books?id=n-O_AAAACAAJ.

${ }^{27}$ Hasil wawancara dengan Kyai Ali Shobirin, 4 Maret 2020

${ }_{28}$ Bernard M. Bass dan Ruth Bass, The Bass handbook of leadership: Theory, research, and managerial applications (Simon and Schuster, 2009). 
tersebut terhadap para pengikutnya. Para pemimpin transformasional membuat para pengikutnya menjadi lebih peka akan pentingnya hasil-hasil dari pekerjaan, mengaktifkan kebutuhan-kebutuhan pada tingkat yang lebih tinggi, dan menyebabkan para pengikut memindahkan kepentingan diri sendiri untuk kepentingan organisasi. ${ }^{29}$

Lebih jauh lagi Terkait dengan persoalan kepemimpinan transformasional, Leithwood dan Jantzi ${ }^{30}$ berpendapat bahwa hadirnya gaya atau tipe kepemimpinan transformasional sangat potensial dalam membangun komitmen tingkat tinggi (high levels of commitment) pada diri bawahan untuk merespon kompleksitas dan ketidak pastian yang bersifat alami atau warisan tradisi dari agenda reformasi organisasi. Dengan kapasitas kepemimpinan transformasional ini juga akan mempermudah usaha mempercepat atau pemercepatan pertumbuhan kapasitas bawahan dalam mengembangkan diri untuk merespon secara positif agenda pengembangan organisasi (pondok pesantren) ${ }^{31}$.

\section{Tipe Pemimpin Kharismatik}

Memang kepemimpinan kharismatik kyai bisa dilihat dari sisi kewibawaan yang sangat tinggi, kenapa beliau kyai Ali Shobirin menjadi sangat wibawa karena tidak hanya berbicara ilmu tapi juga mengimplementasikan ilmu dalam kehidupan sehari-hari dan didalam mengelola pondok pesantren tidak tergantung kepada pemerintah akan tetapi bagaimana mengelola pondok pesantren dengan usaha ekonomi mandiri yang dikembangkanya. Menurut weber dalam Arifin menjelaskan bahwa kepemimpinan karismatik merupakan kepemimpinan daya tarik tersendiri terhadap orang yang mengikutinya.kemapuan kyai yang mampu mempengaruhi orang lain dengan wibawa dan spritualitas yang tinggi dimiliki oleh Kyai. ${ }^{32}$

Kepemimpinan beliau sangat nampak juga dimasyarakat dengan mengadakan rutinan sholawatan,pembacaan rothibul hadad yang dilakukan keliling bergantian dari musholamushola yang ada di kasembon ,hal ini juga menajadi satu daya tarik luar biasa dalam model kepemimpinan beliau untuk mengajak dengan cara yang sangat halus agar masyarakat dekat dengan Allah SWT dan menjadikan kampong atau daerah menjadi aman tentram dengan

\footnotetext{
${ }^{29}$ Gary A. Yukl, “Kepemimpinan dalam Organisasi: Leadership in Organization 3 e,” 2017, 297.

30 Sudarman Danim, Menjadi Komunitas Pembelajar; Kepemimpinan Transformasional dalam Komunitas Organisasi Pembelajar. Jakarta: bumi aksara, 2003, h. 53.

${ }^{31}$ Danim, Menjadi komunitas pembelajar: kepemimpinan transformasional dalam komunitas organisasi pembelajaran.

32 Zaenal Arifin, "Kepemimpinan Kiai Dalam Ideologisasi Pemikiran Santri Di Pesantren-Pesantren Salafiyah Mlangi Yogyakarta,” INFERENSI: Jurnal Penelitian Sosial Keagamaan 9, no. 2 (1 Desember 2015): 35172, https://doi.org/10.18326/infsl3.v9i2.351-372.
} 
berdoa bersam-sama. Dari sisi yang lain juga bisa menjadi ajang silaturahmi antar pondok pesantren al qoyyim dengan masyarakat sekitar.

Disampaikan oleh salah satu ustad yang ada dipondok al qoyyim bahwa kyai Ali Sobirin mempunyai satu pendekatan yang sangat damai ke santri dan masyarakat, dengan pendekatan tsawwuf yang selalu menebarkan kedamaian kesemua mahluk ciptaan Allah SWT. ${ }^{33}$

Yulk dalam Sudaryono ${ }^{34}$ memberikan indikator kepemimpinan karismatik sebagai berikut : (1) pengikut-pengikutnya meyakini kebenarannya dalam cara memimpin. (2) pengikut-pengikutnya menerima gaya kepemimpinannya tanpa bertanya. (3) pengikut pengikutnya memiliki kasih sayang kepada pemimpinnya. (4) kesadaran untuk mematuhi perintah pemimpinnya. (5) dalam mewujudkan misi organisasi melibatkan pengikutnya secara emosioanal. (6) mempertinggi pencapaian kinerja (performance) pengikutnya. (7) dipercayai pengikutnya bahwa kepemimpinannya akan mampu mewujudkan misi organisasinya.

Sedangkan menurut Susanto Para pengikut pemimpin karismatik sering bersikap labil dan mudah berubah. Hingga batas tertentu mereka sangat loyal dan loyalitasnya nyaris mengabaikan kewajiban kerjanya dan menjual sesuatu untuk mengikuti anjuran pemimpinnya. ${ }^{35}$ Dengan demikian antara pemimpin dan pengikut terkonstruksi hubungan erat, layaknya sebuah keluarga, dan hubungan demikian, juga terjalin di antara sesama pengikut dalam komunitas

Melihat dari penjelasan yang disampaikan oleh Yulk dan Susanto bahwa kepemimpinan kyai Ali Shobirin bisa ditarik dalam beberapa komponen kepemimpinan karismatik dalam pembentukan karakter mandiri santri di Pondok Pesantren Al Qoyyim terbagi menjadi beberapa peran diantaranya yaitu; 1) Kyai Sebagai Pengasuh;2) Kyai sebagai orang tua kedua santri; 3) Kyai sebagai Teladan; 4) Kyai Sebagai Pemimpin; dan 5) Kyai sebagai motivator. Dengan menggunakan indikator kepemimpinan karismatik berikut: 1) pemimpin karismatik sangat dipercayai oleh bawahannya; 2) Memiliki visi dan tujuan yang amat kuat dan ideal; 3) Berani dan tegas dalam menyampaikan visinya; 4) Dipahami sebagai agen perubahan; 5) Memberikan keteladanan yang baik terhadap anggotanya;6) Mempunyai

${ }^{33}$ Hasil wawancara dengan Ustad Fiki salah satu pengajar di Pondok Pesantren Al Qoyyim,Wawancara,5 Maret 2020.

34 Sudaryono, 2014. Leadership: Teori dan Praktek Kepemimpinan, Jakarta Pusat : Lentera Ilmu Cendekia.

35 Edi Susanto, "Krisis Kepemimpinan Kiai: Studi atas Kharisma Kiai dalam Masyarakat," ISLAMICA: Jurnal Studi Keislaman 1, no. 2 (2014): 111-120. 
kepekaan terhadap pengikut dan lingkungannya. Kekharismaan kyai Ali Shobirin bisa dilihat dari beberapa sisi sebagaimana berikut.

\section{Kyai Sebagai Pengasuh}

Seorang kyai yang membimbing dan bertanggung jawab kepada santri dan terus memantau perkembangan santri dilakukan siang dan malam.sampai memikirkan bagaimana santri harus betul-betul mendapatkan ilmu dan selalu mendoakan agar bahagia dunia dan akhiratnya. Ini dilakukan olek kyai Ali shobirin sebagai pengasuh pondok pesantren al Qoyyim kasembon. Dengan cara ada rutinan setiap hari ngaji yang dibina langsung oleh kyai dan melakuka sholat malam serta dzikir .

Seperti disampaikan oleh salah satu Ustad bahwa Kepekaan kyai ali shobirin terhadap santrinya ialah ketika waktunya ngaji dan santri belum bergegas segera beliau mengiatkan untuk segera menuju tempat menagaji ,seperti wirid malam dan sholat lima waktu kyai langsung mengontrol santri-santrinya. ${ }^{36}$

Hal ini sependapat dengan teori Nawawi dalam Sudaryono ${ }^{37}$ yang mengemukakan bahwa karakteristik utama kepemimpinan karismatik adalah meiliki kepekaan terhadap lingkungan secara realistis, melaksanakan manajemnen sumber daya untuk perubahan.

Kyai Ali Shobirin selain sangat peduli dengan para santrinya, beliau juga memikirkan dhohir dan bathin, tidak hanya menyiapkan kebutuhan materinya akan tetapi juga melakukan ketegasan agar santri betul-betul menjalankan ajaran Islam.

Bahwa beliau sangat tegas ketika membicarakan perintah agama,seperti sholat,membaca al quran,wirid dan berwirausaha yang lainnya. Para santri harus betul-betul mengikuti program bangun malam,sholat tahud dan dzikir-dzikir. ${ }^{38}$

Semua yang dilakuka itu sesuai dengan visi yang diinginkan oleh pengasuh pondok pesantren karena kita ketahui bahwa menurut Dhofier Metode yang diterapkan pesantren pada prinsipnya mengikuti selera kyai, yang dituangkan dalam kebijakan-kebijakan pendidikannya. Dari perspektif metodik, pesantren terpolarisasikan menjadi tiga kelompok: Pertama, kelompok pesantren yang hanya menggunakan metode yang bersifat tradisional dalam mengajarkan kitab-kitab Islam klasik. Kedua, kelompok pesantren yang hanya menggunakan metodemetode hasil penyesuaian dengan metode yang dikembangkan pendidikan formal. Ketiga, pesantren yang menggunakan metode-metode yang bersifat

\footnotetext{
${ }^{36}$ Hasil wawancara dengan Ustad Fiki, 12 Februari 2020).

37 Sudaryono, 2014. Leadership: Teori dan Praktek Kepemimpinan, Jakarta Pusat : Lentera Ilmu Cendekia.

${ }^{38}$ Hasil Wawancara dengan ustad Fiki,12 Maret 2020).
} 
tradisional dan mengadakan penyesuaian dengan metode pendidikan yang dipakai dalamlembaga pendidikan formal. ${ }^{39}$

Kyai Ali Shobirin ini betul-betul menggabungkan dari kekuatan spiritual,intelektual dan ketrampilan. Apalagi santri-santri disini tidak mengeluarkan biaya untuk belajar dipondok pesantren dan justru juga disekolahkan secara gratis serta diberikan ketrampilan yang memadai.

\section{Kyai Sebagai Orang Tua}

Orang tua santri menempatkan anaknya agar menuntut ilmu di pondok pesantren al Qoyyim menginginkan kelak agar mempunyai kemampuan ilmu al quran dan mempunyai akhlakul karimah yang baik. yang sangat menarik di pondok pesantren Al Qoyyim ini betulbetul menjadi rumah sendiri bagi santri karena disini juga tidak dipungut biaya semua menjadi tanggungan pengasuh pondok pesantren,ini menjadikan kepercayaan orang tua yang sangat tinggi kepada pondok pesantren. Dan hal yang sama disampaikan dalam wawancara dengan ustadz fiki bahwa:

Bapak kyai ali shobirin ini,sangat dekat sekali dengan santri sampai-sampai seperti dengan orang tua asli. Mengurusi mulai dari kehidupannya ,makannya,pendidikannya dan akhlaknya santri. ${ }^{40}$ Mengacu dari teori yulk dalam marganingsih bahwa kepemipinan karismatik memiliki perilaku yang dipercaya anggotanya bahwa pemimpin memiliki kompetensi sehingga keputusan atau kebijakan yang diambil seorang pemimpin akan memberikan kesan dan kepercayaan bagi anggotanya dan pada akhirnya menjadikan patuh serta ta'at atas kebijakan yang dikeluarkan ${ }^{41}$.

Kepatuhan santri kepada kyai tidak hanya disebabkan kampetensi yang dimiliki seorang kyai akan tetapi komunikasi yang baik dengan santri,keakraban kayai dengan santrinya seakan-akan menjadi orang tua aslinya, ini yang menjadikan santri betul-betul taat. Seperti yang disampaikan salah satu santri bahwa Kekaraban kyai ali shobirin ini juga menjadikan santri akan selalu jujur kepada beliau . Kata salah satu santri bahwa saya tidak berani berbohong disebabkan kedekatan saya denga pak kyai. ${ }^{42}$

Kasih sayang,kepedulian dan memjadikan kedekatan dalam berkomunikasi inilah menjadikan Kyai seperti orang tua kandungnya,karena merasa tentram damai ketika dekat dengan seorang kyai.

${ }^{39}$ Dhofier, Tradisi pesantren, 30.

${ }^{40}$ Hasil wawancara dengan ustad fiki,12 Februari 2020).

${ }^{41}$ Ria Marginingsih, "Kepemimpinan karismatik sebagai employer branding," Jurnal Bisnis Darmajaya 2, no. 2 (2017): 32-51.

${ }^{42}$ Hasil wawancara dengan salah satu santri al qoyyim, 12 Desember 2019 


\section{Kyai Sebagai Motivator}

Menurut Ansor Kepemimpinan Karismatik Kyai merupakan kepemimpinan yang mendapat anugerah yang Maha Kuasa dan pemimpin yang memiliki karisma dianggap mempunyai kemampuan supranatural, yang dapat memotivasi para pengikutnya rela berkorban untuk sebuah ide dan gagasan pemimpin. ${ }^{43}$

Seperti yang ada di pondok pesantren Al Qoyyim pengasug selalu memotivasi kepada santrinya ketika awal masuk ke pesantren sampai nanti lulus, disampaikan oleh salah satu santri: Seperti halnya di pondok pesantren al qoyyim yang setiap awal masuk santri ke pesantren selalu dilakukan pengenalan santri baru dan orientasi santri baru. Dan selalu diberi semangat oleh kyai ali shobirin. Seperti apa yang disampaikan oleh sifak alumni pondok pesantren al qoyyim bahwa romo yai selalu memberikan motivasi kepada santri baru agar selalu berniat menuntut ilmu karena Allah dan untuk kehidupan masa depan yang lebih baik. ${ }^{44}$

Kesemangat untuk selalu memberikan teladan dan motivasi terhadap santri dan masyarakat menjadikan pengasuh banyak pengikutnya, ini juga disebabkan karena memberikan inspirasi kepada santri dan masyarakat. Bahwa Pemimpin karismatik biasanya memiliki pengikut yang banyak dan memiliki loyalitas yang luar biasa. Sesungguhnya kharisma Kyai memperoleh dukungan masyarakat, hingga batas tertentu, disebabkan karena dia dipandang memiliki kemantapan moral dan kualitas keimanan yang melahirkan suatu bentuk kepribadian magnetis bagi para pengikutnya. Proses ini, mula-mula beranjak dari kalangan terdekat, sekitar kediamannya, yang kemudian menjalar ke luar ke tempat-tempat yang jauh. Kharisma yang dimiliki Kyai tersebut dalam sejarahnya mampu menjadi sumber dan inspirasi perubahan dalam masyarakat. ${ }^{45}$

Menurut Bryan S. Turner dalam Susanto Kyai dengan kharisma yang dimilikinya tidak hanya dikategorikan sebagai elit agama, tetapi juga sebagai elit pesantren dan tokoh masyarakat yang memiliki otoritas tinggi dalam menyimpan dan menyebarkan pengetahuan keagamaan Islam serta berkompeten dalam mewarnai corak dan bentuk kepemimpinan terutama dalam pesantren. ${ }^{46}$

43 Ahmad Sofan Ansor, "Manajemen Pendidikan Islam Tentang Kepemimpinan Kiai Di Pondok Pesantren Tahfidz Daarul Quran Cipondoh Tangerang," Edukasi Islami: Jurnal Pendidikan Islam 3, no. 06 (2017).

${ }^{44}$ Hasil Wawancara dengan M. rohman salah satu santri Pondok pesantren al Qoyyim 12 Februari 2020).

45 Edi Susanto Edi Susanto, "Kepemimpinan [Kharismatik] Kyai Dalam Perspektif Masyarakat Madura," KARS A: Journal of Social and Islamic Culture 11, no. 1 (2012): 30-40.

${ }^{46}$ Ibid, Jurnal Islamic, Vol.1, No 2, Maret 2007 
Semua bisa berjalan dengan alamiah dan tidak dibuat-buat, dipondok al Qoyyim juga mempunyai ruh motivasi yang kuat dimiliki pengasuh dan memberikan pancaran kekuatan kepada para santri dan masyarakat untuk bisa hidup dengan damai ,dan penuh kebahagian karena semua didasarkan atas apa adanya bukan dipaksakan untuk ada. Kita bisa lihat banyak dalam kehidupan moderen ini manusia berebut kepalsuan untuk menuju jabatan tertentu ,semua itu menjadikan tidak stabil dalam hidupnya. Dengan belajar dari hidupnya seorang kyai yang penuh ketawaduan,kesabaran ,kesyukuran dan apa adanya maka kehidupan ini akan lebih bermakna dan lebih bahagia.

\section{Pembiasaan Santri Mandiri di Era Industri 4.0}

Pondok pesantren sudah lama menjadi tempat rujukan untuk membentuk manusia yang mandiri dalam hal wawasan,pendiikan dan ekonomi. Bisa dilihat dalam sjearah Indonesia pesantren sebagai tempat untuk menngembleng para santri agar berkarakter,tidak hanya dalam pemahaman tapi dengan pelatihan,pembiasaan dan pembinaan. ${ }^{47}$ Sedangkan menurut Dhofier bahwa pondok peasntren memiliki ciri yang khas dan tidak dimiliki lembaga formal lainnya yaitu mempunyai sifat karismatik dan suasana kehidupan keagamaan yang mendalam. ${ }^{48}$

Pondok pesantren sekarang tidak bisa lari dari era revolusi industry 4.0 akan tetapi justru harus mampu memberikan jawaban konkrit kepada para santri agar nantinya mampu eksis ditengah-tengah era yang serba teknologi. Menurut schwab bahwa revolusi industry telah merubah kehidupan dan kerja manusia secara mendasar. Revolusi generasi 4 ini memiliki skala ruang lingkup yang sangat komplek, mulai dari kemajuan teknologi yang mengintegrasikan dunia fisik,digital dan biologis, semua itu mempengaruhi semua disiplin ilmu,ekonomi,industry dan pemerintahan.

Disinilah membutuhkan satu pendekatan yang berbeda agar pondok pesantren agar tetap eksis dan santrinya mampu bersaing yaitu dengan mencetak santri yang mandiri dari bermacam-macam bidang. Hal ini seperti yang dilakukan di pondok pesantren al Qoyyim bahwa:

Dipondok pesantren al qoyyim diajarkan untuk memahami beberapa bidang mulai dari bidang agama, bidang ekonomi,sosial dan ketrampilan. Ketrampilan santri inilah yang menjadikan nanti sebagai alumni yang siap didalam menjalani hidup di era 4.0. ${ }^{49}$

47 Rela Mar'ati, "Pesantren Sebagai Basis Pendidikan Karakter; Tinjauan Psikologis," Al-Murabbi: Jurnal Studi Kependidikan Dan Keislaman 1, no. 1 (2014): 1-15.

48 Dhofier, Tradisi pesantren, 45.

${ }^{49}$ Hasil wawancara dengan pengasuh pondok pesantren al Qoyyim, 12.Februari.2020 
Sekarang ini menjadi taruhan dari semua pondok pesantren apakah mampu mencetak santri yang mandiri atau tidak karena revolusi industri mengalami puncaknya saat ini dengan lahirnya teknologi digital yang berdampak masif terhadap hidup manusia di seluruh dunia. Revolusi industri terkini atau generasi keempat mendorong sistem otomatisasi di dalam semua proses aktivitas. Teknologi internet yang semakin masif tidak hanya menghubungkan jutaan manusia di seluruh dunia tetapi juga telah menjadi basis bagi transaksi perdagangan dan transportasi secara online. Munculnya bisnis transportasi online seperti Gojek, Uber dan Grab menunjukkan integrasi aktivitas manusia dengan teknologi informasi dan ekonomi menjadi semakin meningkat. Berkembangnya teknologi autonomous vehicle (mobil tanpa supir), drone, aplikasi media sosial, bioteknologi dan nanoteknologi semakin menegaskan bahwa dunia dan kehidupan manusia telah berubah secara fundamental.

Dari sinilah pondok pesantren al Qoyyim membiasakan sikap-sikap santri agar nanti menjadi santri yang menguasai beberapa bidang dan mampu bersaing di era revolusi industri, yaitu sebagai berikut:

\section{Pembiasaan Sikap Disiplin}

Disiplin merupakan kesadaran diri yang muncul dari batin terdalam untuk mengikuti dan menaati peraturan-peraturan, nilai-nilai hukum yang berlaku dalam satu lingkungan tertentu. ${ }^{50}$ Sedangkan menurut chaplin dalam yusuf bahwa "berdisiplin itu mampu mengatur tingkah lakunya sendiri. Disamping itu mempunyai tanggung jawab untuk merencanakan kegiatannya sendiri.

Kedisiplinan ini sangat nampak didalam kehidupan santri yang ada di pondok pesantren al Qoyyim, para santri sangat sadar bahwa harus bisa mengatur waktunya ,dimana santri harus selalu bisa mengikuti kegiatan sholat berjamaah, sebagaimana disampaikan oleh ustad fiki:

Mengajarkan dan mengajak para santri untuk menjalankan sholat jamaah tidak perkara mudah apalagi kalau santri yang masih dibilang baru dan masih umur setingkat MI, akan tetapi membutuhkan proses agar berjalan dengan efektif. Dipondok sini bisa dibilang sudah tertib para santri untuk mengikuti sholat berjamaah lima waktu serta mengikuti dzikir setelah sholat sampai selesai. ${ }^{51}$

50 Tu’u, T. Peran Disiplin Pada Perilaku dan Prestasi. Jakarta: Gramedia Widiasarana Indonesia

51 Hasil wawan cara dengan ustad fiki salah satu ustda yang ada di pondok pesantren al Qoyyim, 12 Februari 2020 
Hal yang senada bahwa santri sangat disiplin ketika adzan berkumandang ,para santri langsung berkumpul dimasjid untuk bersiap-siap melakukan sholat berjamaah dan santri senior melakukan pengawasan dan absensi. ${ }^{52}$

Perlakuan kepada santri untuk selalu melakukan sholat berjamaah dengan tertib,sesungguhnya cara mencetak santri agar tumbuh sebagai manusia yang disiplin. Ketika dalam sholat berjamah mampu melakukan dengan kesadaran maka dengan sendirinya sikap disiplin ini otomatis akan terbentuk dalam diri santri.

Pelaksanaan disiplin ini tidak hanya didalam sholat jama'ah saja akan tetapi juga tentang amaliyah sehari-hari yang harus dilakukan seperti merawat ayam, merawat usaha ikan mujair yang ditambak dan merawat kambing serta beberapa usaha yang ada dipondok pesantren al Qoyyim. Senada apa yang disampaikan oleh ustad fiki:

Dipondok pesantren sini santri harus juga belajar untuk disiplin waktu untuk bisa membagi waktu kapan untuk belajar dan merawat ayam,ikan lele, ikan mujair ${ }^{53}$ Sikap disiplin juga dilakukan melalui pembiasaan agar santri bisa merawat dirinya sendiri dari mencuci baju,memasak dan membersihkan kamar tidur. Sesuai hasi observasi bahwa Para santri setiap pagi dan sore bergantian dijadwal untuk melakukan masak nasi dan lauk untuk kebutuhan dirinya. Dan mencuci baju ,serta setiap pagi menyapu serta merapikan kamar tempat tidurnya. ${ }^{54}$

Dari sinilah menurut Langevel seperti yang dikutip oleh Soelaiman mengatakan bahwa mandiri ialah kemampuan seseorang untuk mengambil keputusan atas kehendaknya sendiri dalam melakukan sebuah tindakan. ${ }^{55}$ Steinberg dalam Kusumawardhani $^{56}$ mengungkapkan terdapat beberapa aspek kemandirian, yaitu a) kemandirian emosi, b) kemandirian bertindak dan c) kemandirian dalam nilai. Yang dijelaskan sebagai berikut. a). Kemandirian Emosi (Emotional Autonomy), yakni kemampuan remaja untuk melepaskan diri dari ketergantungan orang tua dalam pemenuhan kebutuhan-kebutuhan dasarnya, b). Kemandirian Bertindak (Behavioral Autonomy), merupakan kemampuan remaja untuk melakukan aktivitas, sebagai manifestasi dari berfungsinya kebebasan, menyangkut peraturan-peraturan yang wajar mengenai perilaku dan pengambilan keputusan, dan $\boldsymbol{c}$ ). Kemandirian Nilai (Value Autonomy), yakni

${ }^{52}$ Hasil Observasi pada tanggal 14 september 2019

${ }^{53}$ Hasil wawancara dengan fiki, 14 september 2019

${ }^{54}$ Hasil observasi 14 september 2019

${ }_{55}$ DR Namora Lumongga, Memahami dasar-dasar konseling dalam teori dan praktik (Kencana, 2014).

56 Arifah Kusumawardhani, Sri Hartati, dan Imam Setyawan, "Hubungan kemandirian dengan adversity intelligence pada remaja tuna daksa di SLB-D YPAC Surakarta,” 2010. 
kebebasan untuk memaknai seperangkat prinsip tentang benar dan salah, yang wajib dan yang hak, yang penting dan yang tidak penting. Kepercayaan dan keyakinan tersebut tidak dipengaruhi oleh lingkungan termasuk norma masyarakat.

Santri dibentuk untuk menjadi manusia yang mandiri secara emosi ketidak tergantungan kepada orang tua Karena di pondok pesantren jauh dari orang tua mau tidak mau harus melakukan semuanya dengan mandiri. Juga santri harus mandiri secara bertindak dan kemandirian dalam nilai. Kemandirian sebagai nilai, memerlukan proses yang panjang dan bertahap melalui berbagai pendekatan yang mengarah pada perwujudan sikap. Karena itu, pendidikan kemandirian lebih menekankan pada proses-proses pemahaman, penghayatan, penyadaran dan pembiasaan ${ }^{57}$.

\section{Pembiasaan Santri Berwirausaha}

Menurut Alma, bahwa wirausaha ialah orang yang selalu melihat ada peluang dan kemudian menciptakan sebuah sesuatu yang terencana untuk memanfaatkan peluang tersebut. Sedangkan proses kewirausahaan meliputi kegiatan fungsi dan tindakan untuk mengejar peluang dengan menciptakan sistem ${ }^{58}$.

Sedangkan menurut Wibowo ${ }^{59}$ wirausaha ialah orang yang sangat terampil dalam memanfaatkan peluang mengembangkan usahanya, dengan tujuan untuk meningkatkan kehidupannya. Penekanan santri pondok pesantren al Qoyyim agar nanti menjadi wirausaha tidak main-main, ini dimlai ketika masih nyantri. Santri putra sudah diajari paraktik langsung dan ditambah dengan pelatihan-pelatiahan. Hal ini disampaikan oleh pengasuh pondok:

Santri disini mulai sejak dini ketika nyantri disini sudah diajarakan agar menjadi wirausaha,dengan cara santri langsung praktik wirausaha,misalkan santri putra mencoba langsung bertenak ayam ikan lele da nada juga cacing. ${ }^{60}$ Kalau kita lihat pengasuh pondok mempunyai kesungguhan ingin sekali santri nanti bisa menjadi pendakwa yang bisa mengambil peluang untuk melakukan usaha dan tidak tergantung kepada orang lain. Dalam mengajarkan berwirausaha pengasuh pondok melakukan dua tahapan skema yang pertama memahami teoirinya dulu atau pengetahuannya dulu baru praktik ,ada yang

57 Muhammad Anas Ma`arif dan Ari Kartiko, "Fenomenologi Hukuman di Pesantren: Analisis Tata Tertib Santri Pondok Pesantren Daruttaqwa Gresik," Nadwa 12, no. 1 (22 Juni 2018): 181-96, https://doi.org/10.21580/nw.2018.12.1.1862; Dewi Nurul Qomariyah, "Manajemen Pondok Pesantren Dalam Pemberdayaan Santri," FENOMENA 12, no. 2 (2016).

58 Buchari Alma, "Kewirausahaan," Bandung: Alfabeta, 2013.

59 Agus Wibowo, "Pendidikan Kewirausahaan (konsep dan strategi)," Yogyakarta: Pustaka Pelajar, 2011.

${ }^{60}$ Hasil wawancara dengan kyai Ali Shobirin, 14 Mei 2020 
langsung belajar ditempat usaha dan hidup disitu beberapa minggu untuk langsung praktik. Dijelaskan oleh kyai ali shobirin:

Santri sini agar bisa mempunyai mental wirausaha,dilakukan pelatihan-pelatihan wirausaha setelah itu harus mempraktikannya,misalnya setelah belajar untuk bertenak ayam,lele atau cacing langsung dipraktikan itu untuk santri putra . sedangkan untuk santri putri pealatihan tata busana,rias dan itu juga langsung dipraktikan ketika selesai pelatihan. ${ }^{61}$

Apa yang dilakukan oleh pengasuh pondok pesantren al Qoyyim ini sesuai dengan apa yang disampaikan oleh Astiti bahwa pendidikan kewirausahaan ialah sebagai usaha yang dilakukan lembaga untuk menanamkan pengetahuan, nilai, jiwa dan sikap wirausaha. Maka untuk mencetak wirausaha harus melalui sistem yang konkrit yang dialkukan oleh lembaga dan pengasuhnya. Yang menarik lagi Pengajaran wirausaha langsung dibimbing oleh kyainya dengan bekerjasama dengan pengembangan SDM LAGZIZ Malang,dengan mengikuti pelatihan dengan para ahli,berwirausaha dengan belajar langsung kepada ahlinya. Seperti disampaikan oleh kyai Ali Shobirin:

Pondok ini sering mengirim santri ke malang kota untuk belajar langsung ke ahli wirausaha yang itu dengan LAGZIZ Malang,setelah dari pelatihan langsung praktik. ${ }^{62}$ Santri dipondok pesantren Al Qoyyim langsung melakukan praktik usaha dengan merawat ternak ayam,lele,mujair dan juga ada ternak kambing, serta juga ada pembuatan Es krim. Semua ini dilakukan oleh pondok pesantren agar santri nanti mempunyai keahlian dalam berdakwah dimasyarakat. Menurut Wibowo bahwa wirausaha merupakan orang yang memilikikarakter wirausaha dan mengaplikasikan hakikat kewirausahaan itu daklam kehidupannya dan orang wirausaha memeiliki jiwa kreatifitas,inovasi yang tinggi dalam hidupnya. ${ }^{63}$

Menjadi tidak kalah pentingnya lagi adalah bahwa dalam berwirausaha di era Industri 4.0 ini,para santri sudah menggunakan media sosial sebagai wadah untuk memasarkan hasil dari usaha yang sudah digelutinya. Menurut pengasuh pondok al Qoyyim bahwa santri sudah memanfaatkan media sosial untuk berjejaring dan jualan onlain. Para santri sudah tidak gaptek dengan computer dan tentang informasi teknologi.

\footnotetext{
${ }^{61}$ Hasil wawancara dengan kyai Ali Shobirin, 14 Mei 2020

${ }^{62}$ Hasil wawancara dengan kyai Ali Shobirin, 14 Mei 2020

${ }^{63}$ Wibowo, "Pendidikan Kewirausahaan (konsep dan strategi)."
} 


\section{Model Kepemimpinan Kyai dalam mencetak santri mandiri di Era 4.0}

Menurut Ackoff, model dapat dipandang dari tiga jenis kata yaitu sebagai kata benda, kata sifat dan kata kerja. Sebagai kata benda, model berarti representasi atau gambaran, sebagai kata sifat model adalah ideal, contoh, teladan dan sebagai kata kerja model adalah memperagakan, mempertunjukkan. Dalam pemodelan, model akan dirancang sebagai suatu penggambaran operasi dari suatu sistem nyata secara ideal dengan tujuan untuk menjelaskan atau menunjukkan hubungan-hubungan penting yang terkait ${ }^{64}{ }^{65}$

Kalau disinkronkan dengan kyai Ali Shobirin bahwa bisa dilihat dari input santri yang masuk dari kebanyakan anak dari keluarga yang kurang mampu,setelah itu didik dengan sangat sabar agar nantinya santri menjadi manusia yang bisa memberikan kemanafaatkan banayak orang. Proses yang dilakukan mulai dari pelatihan-pelatihan wirausaha setelah itu mempraktikan teori yang sudah dipahami dan melakukan inovasi pengembangan agar tetap eksis dalam dunia usaha.

Kyai Ali Shobirin juga termasuk pemimmpin yang mempunyai karakter visioner,transformational dan kharismatik. Didalam memimpin lembaga kyai Ai shobirin sudah melakukan keterbukaan dalam mengembangkan lembaga. Akan tetpai bagaimanapun seorang kyai yang selaku pendiri dan pengasuh mempunyai kekuatan dalam menentukan kebijakan-kebijakan pondok pesantren. maka dari sinilah beliau termasuk model kepemimpinan individual-kolektif. Semua ini juga dirasakan oleh para santri dan masyarakat sekitar bahwa kyai Ali Shobirin memang sebagai pendiri dan sekaligus pengasuh serta sebagai orang tua kedua dari para santri ,sikap yang terbuka yang dimiliki menjadikan santri sangatlah dekat dengan beliau. Masyarakat juga merasakan keterbukaan dengan selalu bekerjasama dengan warga sekitar untuk melakukan kegiatan-kegiatan keagamaan dan sosial.

\section{KESIMPULAN}

Didasarkan dalam pembahasan penelitian ini bahwa kyai Ali Shobirin adalah pemimpin yang masuk dalam tiga tipe yaitu tipe pertama, Pemimpin yang visioner mempunyai harapan atau visi besar dimasa yang akan datang agar santrinya sukses dunia dan akhirat serta mempunyai cita-cita punya 100 cabang pondok pesantren. Kedua, pemimpin Transformasional yang memberikan kepercayaan kepada putranya dan santri seniornya untuk

${ }^{64}$ Russell Lincoln Ackoff, "Scientific method: Optimizing applied research decisions," 1962.

65 Ackoff, Russel L. 1962. Scientific Method Optimizing Applied Research Decisions.New York and London : John Wiley \& Son, Inc 
memimpin pondok cabang. Ketiga, Pemimpin yang kharismatik disebabkan beliau tidak hanya memberikan dawuh secara lisan akan tetapi juga langsung dengan tindakan.

Pembiasaan santri untuk mencetak santri yang mandiri di Era Revolusi Industri 4.0 setidaknya ada beberapa hal yang ditemukan dipondok pesantren al Qoyyim yaitu Pertama, pembiasaan santri agar selalu disiplin, dalam semua hal. Mulai dari ngaji kitab,al quran, sholat berjamaah dan qiyamul lail. yang menarik lagi disiplin dalam merawat usaha yang ada di Pondok Pesantren. Kedua, Pembiasaan santri berwirausaha, ini diprogramkan oleh pengasuh pondok mulai dari belajar teori usaha, setelah itu dipraktikkan dan sampai bagaimana pemasaran onlainnya. Integrasi antara teori, praktik dan paham IT mejadikan lebih mudah dalam berwirausaha yang pada akhirnya santri ketika sudah lulus mampu menjawab tuntutan era Revolusi Industri 4.0.

Setelah melihat pola yang dilakukan kyai Ali Shobirin dalam mengembangkan pondok pesantren untuk mencetak santri mandiri di era Revolusi Industri 4.0, juga melihat dari input dari santri yang masuk setelah itu ada proses yang panjang dan menghasilkan santri-santri yang tangguh dalam menjalankan kehidupan ditengah-tengah masyarakat. Santri serta masyarakat merasakan betul keterbukaan kyai dalam membimbingnya dari beberapa kegiatan yang diselenggarakan, walaupun begitu beliau masih mendominasi dalam melakukan kebijakankebijakan yang berkaitan dengan pondok pesantren al Qoyyim. Hal ini sangat wajar karena beliau selaku pendiri dan pengasuh pondok pesantren al Qoyyim. Maka dari sini kyai Ali Shobirin termasuk Model kepemimpinan individual-kolektif.

\section{REFERENSI}

Aan, Komariah, dan Triatna Cepi. "Visionary Leadership Menuju Sekolah Efektif." Jakarta: Bumi Aksara, 2005.

Achua, C.F., dan R.N. Lussier. Effective Leadership. Canada: South-Western, 2009. https://books.google.co.id/books?id=W-_wPgAACAAJ.

Ackoff, Russell Lincoln. "Scientific method: Optimizing applied research decisions," 1962.

Alam, Naufal Ahmad Rijalul. "Strengthening Leadership Culture (The Role of Kyai in Indonesian Pesantren)." At-Ta'dib 13, no. 1 (2018): undefined-undefined. https://doi.org/10.21111/at-tadib.v13i1.1986.

Alma, Buchari. “Kewirausahaan.” Bandung: Alfabeta, 2013.

Ansor, Ahmad Sofan. "Manajemen Pendidikan Islam Tentang Kepemimpinan Kiai Di Pondok Pesantren Tahfidz Daarul Quran Cipondoh Tangerang.” Edukasi Islami: Jurnal Pendidikan Islam 3, no. 06 (2017). 
Ardiansyah, Mochammad Zaka. "Pesantren Hybrid Worldview: Moderatisasi Paradigma Penalaran Keislaman dan Pemenangan Kontestasi Wacana Daring." Jurnal Pendidikan Agama Islam (Journal of Islamic Education Studies) 7, no. 1 (5 Juli 2019): 1-18. https://doi.org/10.15642/jpai.2019.7.1.1-18.

Arifin, Zaenal. "Kepemimpinan Kiai Dalam Ideologisasi Pemikiran Santri Di PesantrenPesantren Salafiyah Mlangi Yogyakarta." INFERENSI: Jurnal Penelitian Sosial Keagamaan 9, no. 2 (1 Desember 2015): 351-72. https://doi.org/10.18326/infsl3.v9i2.351-372.

Asrohah, Hanun. "The Dynamics of Pesantren: Responses Toward Modernity and Mechanism in Organizing Transformation.” Journal of Indonesian Islam 5, no. 1 (1 Juni 2011): 66-90. https://doi.org/10.15642/JIIS.2011.5.1.66-90.

Bashori, Bashori. "Modernisasi Lembaga Pendidikan Pesantren Perspektif Azyumardi Azra." $\begin{array}{llllll}\text { Nadwa } & 11, & \text { no. } & 2 & \text { (17 }\end{array}$ https://doi.org/10.21580/nw.2017.11.2.1881.

Bass, Bernard M., dan Ruth Bass. The Bass handbook of leadership: Theory, research, and managerial applications. Simon and Schuster, 2009.

Black, J. Stewart, dan Allen J. Morrison. "The Character of Global Leaders.” Dalam Advances in Global Leadership, 8:183-204. Advances in Global Leadership 8. Emerald Group Publishing Limited, 2014. https://doi.org/10.1108/S1535-120320140000008016.

Chairi, Effendi. "Pengembangan Metode Bandongan Dalam Kajian Kitab Kuning Di Pesantren Attarbiyah Guluk-Guluk Dalam Perspektif Muhammad Abid al-Jabiri.” Nidhomul Haq: Jurnal Manajemen Pendidikan Islam 4, no. 1 (15 Maret 2019): 70-89. https://doi.org/10.31538/ndh.v4i1.233.

Chotimah, Chusnul. "Pendidikan Kewirausahaan Di Pondok Pesantren Sidogiri Pasuruan." Inferensi: Jurnal Penelitian Sosial Keagamaan 8, no. 1 (2014): 114-36. https://doi.org/10.18326/infsl3.v8i1.114-136.

Creswell, John W. Qualitative inquiry \& research design: choosing among five approaches. 2nd ed. Thousand Oaks: Sage Publications, 2007.

Danim, S. Menjadi komunitas pembelajar: kepemimpinan transformasional dalam komunitas organisasi pembelajaran. Bumi Aksara, 2003. https://books.google.co.id/books?id=nO_AAAACAAJ.

Darwin, Sudarman. Visi Baru Manajemen Sekolah; Dari Unit Birokrasi ke Lembaga Akademik. Jakarta, 2006. 
Imam Safi i

Dhofier, Zamakhsyari. Tradisi pesantren: studi pandangan hidup kyai dan visinya mengenai masa depan Indonesia. Cet. 8 rev. Jakarta: LP3ES, 2011.

Fauzi, Muhammad Latif. "Traditional Islam in Javanese Society: The Roles of Kyai and Pesantren in Preserving Islamic Tradition and Negotiating Modernity." Journal of Indonesian Islam 6, no. 1 (1 Juni 2012): 125-44. https://doi.org/10.15642/JIIS.2012.6.1.125-144.

Kartiko, Ari, Muhammad Ma`arif, Muhammad Mitra Zuana, Andika Aprilianto, dan Ibnu Rusydi. “The Influence of Leadership, Compensation on Nurses' Performance in the Mother and Child Hospital 'Fatimah' Lamongan.' Indonesia: EAI, 2020. http://dx.doi.org/10.4108/eai.3-10-2019.2291913.

Komariah, Aan, dan Dedy Achmad Kurniady. "Authentic Leadership: Strategy of the Implementation of Madrasah Management of Change." Jurnal Pendidikan Islam 6, no. 2 (27 Desember 2017): 293-310. https://doi.org/10.14421/jpi.2017.62.293-310.

Kusmana, Kusmana. "Pesantren and Local Female Leadership in Modern Indonesia." TARBIYA: Journal of Education in Muslim Society 6, no. 1 (29 Desember 2019): 23-35. https://doi.org/10.15408/tjems.v6i1.8919.

Kusumawardhani, Arifah, Sri Hartati, dan Imam Setyawan. "Hubungan kemandirian dengan adversity intelligence pada remaja tuna daksa di SLB-D YPAC Surakarta,” 2010.

Lexy J, Moloeng. Metodologi penelitian Kualitatif. 29 ed. Bandung: Rosdakarya, 2011.

Lumongga, DR Namora. Memahami dasar-dasar konseling dalam teori dan praktik. Kencana, 2014.

Ma`arif, Muhammad Anas, dan Ari Kartiko. "Fenomenologi Hukuman di Pesantren: Analisis

Tata Tertib Santri Pondok Pesantren Daruttaqwa Gresik.” Nadwa 12, no. 1 (22 Juni 2018): 181-96. https://doi.org/10.21580/nw.2018.12.1.1862.

Manfred, Ziemek. Pesantren Dalam Perubahan Sosial. Jakarta: P3M, 1983.

Mar'ati, Rela. "Pesantren Sebagai Basis Pendidikan Karakter; Tinjauan Psikologis." Al-Murabbi: Jurnal Studi Kependidikan Dan Keislaman 1, no. 1 (2014): 1-15.

Marginingsih, Ria. "Kepemimpinan karismatik sebagai employer branding." Jurnal Bisnis Darmajaya 2, no. 2 (2017): 32-51.

Martin, Van Bruinessen. Kutab Kuning Pesantren dan Tarekat. 1 ed. Yogyakarta: Gading Publising, 2012.

Masrur, Mohammad. "Figur Kyai Dan Pendidikan Karakter Di Pondok Pesantren." Tarbawiyah Jurnal Ilmiah Pendidikan 14, no. 02 (2018): 272-82. 
https://www.mendeley.com/catalogue/ figur-kyai-dan-pendidikan-karakter-dipondok-pesantren/.

Moustakas, Clark E. Phenomenological Research Methods. 6. print. Thousand Oaks, Calif.: Sage Publ, 1999.

Nanus, Burt, dan Frederik Ruma. Kepemimpinan Visioner. Jakarta: Prenhallindo, 2001.

Prasetya, Benny. "Kompetensi Kepribadian Guru Pai Dalam Memotivasi Belajar Siswa." Edukasi: Jurnal Pendidikan Islam 1, no. 2 (2013): 225-238. http://ejournal.staimtulungagung.ac.id/index.php/EDUKASI/article/view/171.

Qomariyah, Dewi Nurul. "Manajemen Pondok Pesantren Dalam Pemberdayaan Santri." FENOMENA 12, no. 2 (2016).

Siswanti, Yuni. Meraih Kepemimpinan Manajerial yang 'smart.' Wimaya Press, Yogyakarta, 2008.

Sudjana, Nana. Penelitian dan penilaian pendidikan. Sinar Baru, Bandung, 1989.

Suharsimi, Arikunto. Prosedur Penelitian, Suatu Pendekatan Teori dan Praktek. 14 ed. Jakarta: Rineka Cipta, 2010.

Susanto, Edi. "Krisis Kepemimpinan Kiai: Studi atas Kharisma Kiai dalam Masyarakat." ISLAMICA: Jurnal Studi Keislaman 1, no. 2 (2014): 111-120.

Susanto, Edi Susanto Edi. "Kepemimpinan [Kharismatik] Kyai Dalam Perspektif Masyarakat Madura." KARS A: Journal of Social and Islamic Culture 11, no. 1 (2012): 30-40.

Wibowo, Agus. "Pendidikan Kewirausahaan (konsep dan strategi)." Yogyakarta: Pustaka Pelajar, 2011.

Yukl, Gary A. “Kepemimpinan dalam Organisasi: Leadership in Organization 3 e,” 2017. 